\title{
DỨBin
}

Technological University Dublin

ARROW@TU Dublin

\section{Crisis and Policy Change: the Role of the Political Entrepreneur}

John Hogan

Technological University Dublin, john.hogan@tudublin.ie

Sharon Feeney

Technological University Dublin, sharon.feeney@tudublin.ie

Follow this and additional works at: https://arrow.tudublin.ie/buschmarart

Part of the Public Affairs, Public Policy and Public Administration Commons

\section{Recommended Citation}

Hogan, John and Feeney, Sharon (2012) "Crisis and Policy Change: The Role of the Political Entrepreneur," Risk, Hazards \& Crisis in Public Policy: Vol. 3: Iss. 2, Article 6.

This Article is brought to you for free and open access by the School of Marketing at ARROW@TU Dublin. It has been accepted for inclusion in Articles by an authorized administrator of ARROW@TU Dublin. For more information, please contact arrow.admin@tudublin.ie, aisling.coyne@tudublin.ie, gerard.connolly@tudublin.ie.

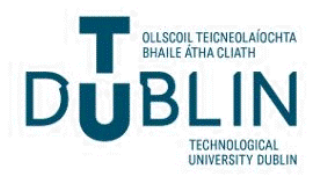




\section{Risk, Hazards \& Crisis in Public Policy}

www.psocommons.org/rhcpp/

Volume 3 , Issue $2 \cdot 2012 \cdot$ Article 6

\section{Crisis and Policy Change: The Role of the Political Entrepreneur}

John Hogan, College of Business, Dublin Institute of Technology Sharon Feeney, College of Business, Dublin Institute of Technology

Hogan, John and Feeney, Sharon (2012) "Crisis and Policy Change: The Role of the Political Entrepreneur," Risk, Hazards \& Crisis in Public Policy: Vol. 3: Iss. 2, Article 6.

(C)2012 Policy Studies Organization 


\title{
Crisis and Policy Change: The Role of the Political Entrepreneur
}

\author{
John Hogan, College of Business, Dublin Institute of Technology \\ Sharon Feeney, College of Business, Dublin Institute of Technology
}

\begin{abstract}
This paper seeks to investigate the inner mechanics of policy change. It aims to discover how ideas enter the political arena, and how endogenous forces within the policy making environment transform ideas into new policies. The central hypothesis is that in times of crisis, new ideas emanate from a number of change agents, but in order for any of these ideas to enter the institutional environment, one specific agent of change must be present: the political entrepreneur. Without political entrepreneurs, ideational change, and subsequent policy change, would not occur. The paper sets out a framework for identifying and explaining the endogenous drivers of policy change, and then tests this framework on two case studies, from two countries.
\end{abstract}

KEYWORDS: crisis, policy, change, political, entrepreneur 
Hogan and Feeney: Crisis and Policy Change

\section{Introduction}

When Sir Ralph Harris, head of the Institute of Economic Affairs (IEA), suggested to Margaret Thatcher that the IEA had been advocating market reform and monetarism two decades prior to her election as Prime Minister, Thatcher quipped: "But remember [Ralph] while the cocks may crow, it's the hen that lays the egg" (Blundell 2008, 8). This captures our paper's hypothesis that, in the context of an exogenous shock (in this case a crisis in the British economy in 1979), the political entrepreneur is the main agent of policy change. The political entrepreneur acts as a bridge between those developing/advocating new policy ideas - policy entrepreneurs (Kingdon 1995), policy networks (Pemberton 2000) or other change agents (Hall 1993) - and the institutions implementing them. In the network of actors contributing to policy change, the political entrepreneur sits at the centre of the process. Without a political entrepreneur to inject the new ideas of policy entrepreneurs into the political arena at times of crisis such as recessions, wars, or political instability, policy change will not occur.

Although the concepts of political and policy entrepreneurship have received attention in the literature, "the concept of policy entrepreneurship is yet to be broadly integrated within studies of policy change" (Mintrom and Norman 2009, 649-650). To address this lacuna, our paper examines case studies from two countries experiencing economic crises during the mid 1970s and early 1980s. Such historical cross-national studies hold considerable promise for achieving a conceptual breakthrough in our understanding of policy change (Mintrom and Norman 2009).

This paper initially discusses the institutional and policy change literature, then examines the various types of change agents before setting out the hypotheses for identifying policy change and testing these against the selected cases. The conclusion highlights the paper's significance and limitations.

\section{Institutional Analysis and Explanations of Change}

The issue of policy change has often been addressed in political science literature through the concept of exogenous shocks. Crises are regularly blamed for destabilising polices. For instance, Greener (2001) argues that exogenous shocks result in new policy paradigms. As a result, the policy change literature (Collier and Collier 1991; Mahoney 2001) has sought to perfect our identification of crises and critical junctures. However, the literature has not paid sufficient attention to the mechanics through which crises result in policy change.

The critical junctures concept was co-opted by path dependence scholars as a means of accounting for change. This is akin to the use of punctuated 
equilibrium in neo-Darwinian evolutionary theory (Gould and Eldredge 1977). Consequently, a regularly invoked interpretation of policy change has divided history into "normal periods" and "critical junctures," during which major change is possible (Gorges 2001). The concepts of critical junctures and exogenous shocks have sometimes been reduced to a deus ex machina to explain change that has proved otherwise inexplicable. Thus, exogenous explanations for sudden and dramatic shifts in policies tend to be crude. Orren and Skowronek (1994) observe that punctuated equilibrium models ignore many of the characteristics of change and ignore endogenous characteristics of change specifically. Thus, the problem here seems to be the use of exogenous shocks in a deterministic fashion that ignores endogenous entities - constituents such as policy and political entrepreneurs - that respectively generate and institutionalise emergent policy ideas. However, without the notion of exogenous shocks to initiate the change process, path dependence is reduced to an equilibrium model. Yet, at a time of crisis, if we can look within an institution for sources of policy change, in terms of idea generation and idea advocacy, we can avoid the necessity of having to rely exclusively upon exogenous explanations for policy change.

Crises expose decision makers to criticism and demands for more effective action (Walsh 2006), resulting in policy change. Yet, sometimes crises do not result in policy changes. What accounts for this inconsistency? Walsh (2006) argues that policy change is most likely to occur when an alternative policy idea can explain past failures and secure the support of powerful constituents. It is to these powerful constituents, capable of generating and advocating alternative policy ideas, that we now turn.

\section{Agents of Change}

The term political entrepreneur, as an explicit concept, was developed by Dahl (1961) (McCaffrey and Salerno 2011). Dahl $(1961,6)$ contended that the political entrepreneur is the crucial agent of change, and "is not so much the agent of others as others are his agents." The political entrepreneur picks and chooses from policy ideas put forward by policy entrepreneurs at times of crisis and shapes the terms of political debate by influencing agendas and constructing cultural frames (Hwang and Powell 2005). They "exploit moments of instability" created by exogenous shocks and "invest resources in the creation of a new policy, or new forms of collective action," having "transformative effects on politics, policies, and institutions" (Sheingate 2003, 188-190).

Kingdon (1995) suggests that change agents encompass a broad grouping of what he terms "policy entrepreneurs." When a policy is in difficulty, due to an exogenous shock for instance, windows of opportunity appear in which policy 
entrepreneurs challenge the existing paradigm (Kingdon 1995). They present a range of new ideas to replace the ones upon which existing policy is based and in the process vie for the attention of politicians to get their ideas into the policymaking environment. Policy entrepreneurs encompass civil servants, technocrats, academics, economists and interest groups, etc. that engage in policy innovation and have some access to decision makers.

Pemberton (2000) identifies change agents as belonging to a policy network schema. In this case, the policy entrepreneurs are essential for advocating new policy ideas to replace failing arrangements at times of crisis. However, the role of the political entrepreneur willing to become an idea's "champion" is crucial. The result is the creation of coalitions among a variety of policy entrepreneurs and the political entrepreneur, whereby "ideas facilitate the reduction of ... barriers by acting as coalition-building resources" (Blyth 2002, 37). Political entrepreneurs are the bridge between those advocating new policy ideas (policy entrepreneurs) and the institutions implementing them. As such, political entrepreneurs, by influencing agendas, shape the terms of political debate (Hwang and Powell 2005). "Successful political entrepreneurs are able to consolidate innovations, producing political or social change that has enduring effects in the form of new programs, policies, or organizations" (Hwang and Powell 2005, 214). This recognises leadership as a situational phenomenon, whereby leaders can take institutions/policies in particular directions (Wallis and Dollery 1997). This paper contends that, at times of exogenous shocks, policy entrepreneurs and outside influences are responsible for producing new ideas, but the political entrepreneur acts as a figurehead, introducing these ideas into the policy process. The political entrepreneur, at the head of an entrepreneurial network of policy entrepreneurs, is capable of engaging in the process of creative destruction in relation to policy.

The relationship between policy and political entrepreneurs can be illustrated by the astronomical concept of a nebula, wherein the gravitational mechanics result in the clustering of particles to produce mass and eventually stars. Like such particles, there are always policy entrepreneurs with policy ideas, swirling around in the policy making environment. In the wake of a crisis, policy entrepreneurs vie for the attention of politicians to get their ideas into the policymaking arena. If a politician is willing to act as a political entrepreneur and champion a new idea, they can draw policy entrepreneurs and other interests to them, building a mass of support behind the policy idea they are advocating (Figure 1). There are advantages for each side in the relationship. The political entrepreneur benefits from the expertise of policy entrepreneurs, to say nothing of their support, while the latter benefit from the politician's "patronage" of their idea in the corridors of power. The more senior the political entrepreneur, and the more determined they are in advancing a particular policy, the greater their 
entrepreneurial potential (Wallis and Dollery 1997). Thus, the process of change is located in the interaction of ideas, actors, and institutions (Hay 2004).

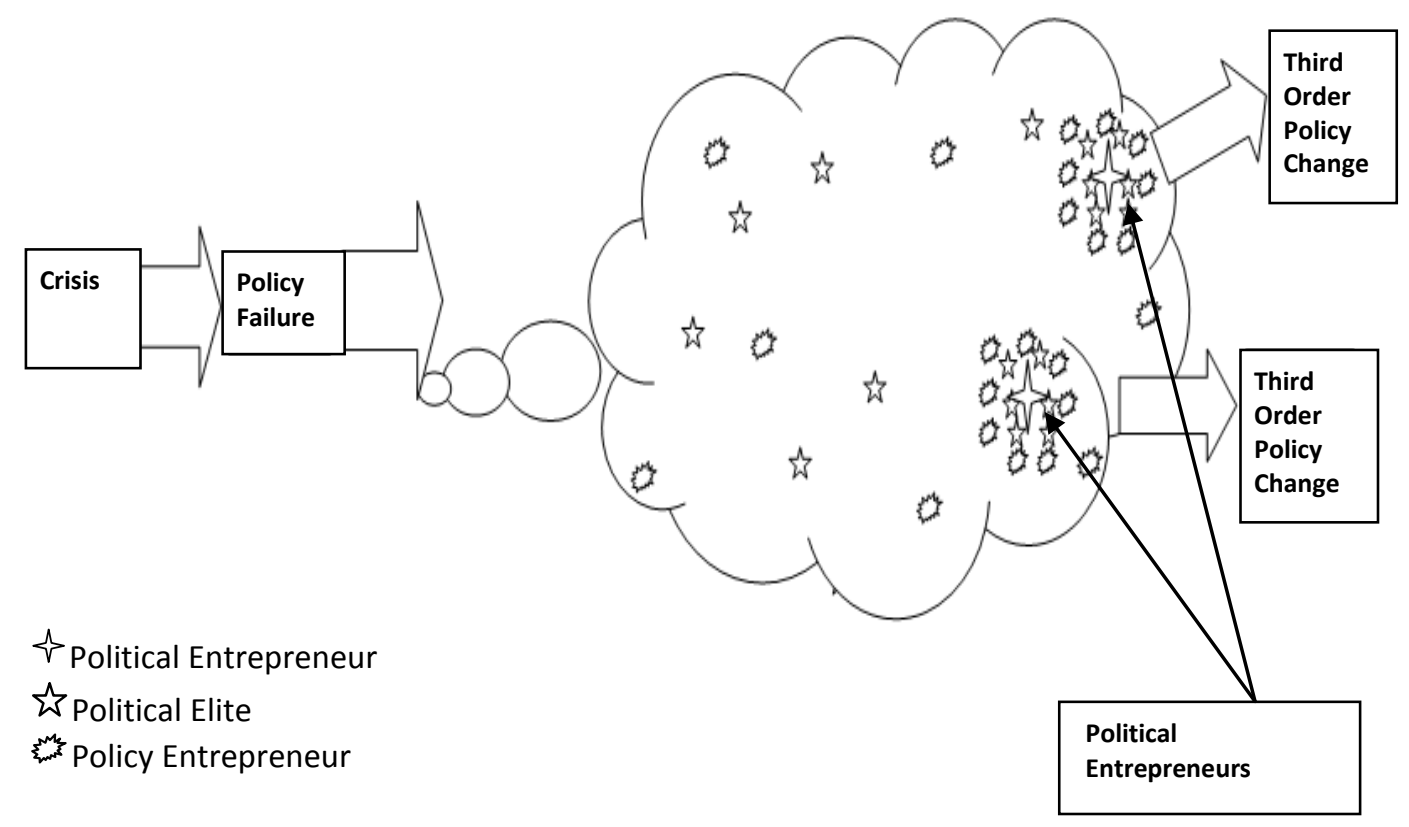

Figure 1. The Policy Change Nebula

\section{Framework for the Identification of Policy Change}

Existing explanations of policy change, while acknowledging the role of policy entrepreneurs, fail to integrate the separate concepts of policy and political entrepreneurship into their transformative frameworks (Mintrom and Norman 2009). This paper seeks to develop an understanding of the endogenous forces driving policy change, wherein the political entrepreneur, interacting with policy entrepreneurs, plays a crucial role. Building on the work discussed above, the paper hypothesizes that policy change occurs in three stages: initiation of the policy debate due to a crisis, ideational change, and the advent of the political entrepreneur. The paper seeks to help explain why, in the wake of certain crises and policy failures, there is policy change, while at other times of crisis no change occurs.

We will measure the nature of policy change using the concepts of first-, second- and third-order change developed by Hall (1993). Hall (1993) argues that exogenous shocks and policy failures can set off processes that lead to ideational change, sometimes resulting in the re-examination of the belief systems through which extant policy has been generated. Thus, this approach provides us with a 
useful tool for understanding degrees of policy change. In Hall's (1993) view, first order change represents a change to policy instrument settings and is a response to policy feedback. Whilst politicians are present in the core decisionmaking network, it is policy entrepreneurs who dominate this process. Second order change is a change to the instruments of policy and their settings and is also driven by policy entrepreneurs, not politicians. In instances of both first and second order change, the overall goals of policy remain the unaltered. However, in third order change, there is change in the instrument settings, the instruments themselves, and the hierarchy of goals behind policy (Hall 1993). In this case it is politicians, and not policy entrepreneurs, who dominate the process. "Such wholesale changes in policy occur relatively rarely" (Hall 1993, 279).

\section{The Initiation of the Policy Debate}

Crises or exogenous shocks are often cited as explanations for policy change (Greener 2001; Golob 2003), as their existence highlights a failing within existing policies due to their implication in, or inability to right, the emergent situation (Levy 1994). In order for policy entrepreneurs to challenge existing arrangements, a crisis and policy failure must be identified and widely perceived (Hay 1999). Agents must diagnose, and impose on others, their notion of a crisis before collective action to resolve the resultant uncertainty can be taken (Blyth 2002). Agents shape "the terms of political debate: they frame issues, define problems and influence agendas" (Sheingate 2003, 188). They ultimately initiate a debate concerning extant ideational orthodoxy.

In terms of macroeconomic shocks, Garrett $(1993,522)$ suggests that "most scholars agree that severe recessions make significant structural changes possible because they render politics highly fluid." A crisis can call into question existing policies, bringing about the possibility of change (Tilly 1975). Accordingly:

Hypothesis 1: A crisis/exogenous shock will initiate debate concerning existing policy arrangements.

\section{Ideational Change}

Once a crisis is identified, the failure of a prevailing policy paradigm drives policymakers to look outside government for a solution (Oliver and Pemberton 2004). Ideas influence policy by acting though particular actors who promote an idea and build a supporting coalition (Berman 1998). As policy entrepreneurs are team players they can constitute an "entrepreneurial network," the composition and size of which can demonstrate the support for an idea (Mintrom and Norman 
2009). The triumph of a new idea from policy entrepreneurs depends upon "a workable new idea being available" which a political entrepreneur is then prepared to promote (Oliver and Pemberton 2004, 419). Such ideas determine the path of subsequent policy, as policymakers work within a framework of ideas and standards that specify not only the goals of policy, but the instruments to be used to achieve these goals, and the nature of the problems they are meant to address (Hall 1993).

Policy entrepreneurs function as a link between problems and the policies introduced by political entrepreneurs to resolve those problems. Political entrepreneurs co-ordinate the policy entrepreneurs, encouraging them to coalesce around a decipherable set of alternative ideas; they are the link between the innovation of the policy entrepreneurs and policy change. Thus, the political entrepreneurs are the drivers of creative destruction.

According to Legro (2000), extant ideational collapse and new ideational consolidation are components of the ideational change process. Should a range of policy entrepreneurs agree that the prevailing paradigm is inadequate, ideational collapse will occur (Legro 2000). In the wake of ideational collapse, the issue is reaching consensus on a new set of ideas. Legro (2000) argues that if consensus is achieved we will then see change agents co-ordinating a replacement set of ideas to the reigning consensus. However, "failure to reach consensus on a replacement could still produce continuity, as society reflexively re-embraces the old orthodoxy" (Legro 2000, 424). Walsh (2006) sees this as the continuation of failed policies due to a lack of coherent intellectual links between policy tools and desired outcomes. In the wake of ideational collapse, a new idea will be adopted if an identifiable political entrepreneur is present to champion it and the idea itself is politically intelligible. As Thatcher suggested, the cock may crow, but there must be a hen to lay the egg. Consequently:

Hypothesis 2: Policy failures will lead to underlying ideational collapse as policy entrepreneurs (entrepreneurial networks) critique the current model and generate replacement ideas, around which they will consolidate if a political entrepreneur is present, resulting in ideational change.

Without a political entrepreneur acting as a type of ideational figurehead/catalyst, this new idea will not enter the institutional environment.

\section{Policy Change}

Hall (1993) argued that exogenous shocks, and policy failures, discredit the old paradigm, leading to a re-examination of the belief systems through which that policy was created. Outlined above is how Hall (1993) describes rare, but radical, 
and overarching changes in policy as third order changes. As we argue that political entrepreneurs are necessary for such paradigm shifts to occur, we are effectively using third order change as the threshold for evaluating the presence of political entrepreneurs. This is because political entrepreneurs exploit the uncertainty created by crises (what Blyth (2002) terms as Knightian uncertainty), and "search for that mix of interests and appeals that can produce a winning coalition" to generate major change (Sheingate 2003, 192). For new ideas to overthrow extant policies the political entrepreneur must occupy a position enabling them to challenge existing arrangements. Political entrepreneurs can be leaders of the governing party or an opposition party, though Oliver (1997) suggests that, for a political party, a period in opposition can be conducive to social learning, allowing it be more open to new ideas. For an idea to triumph, political entrepreneurs must act as ideational coordinators, bringing a broad array of policy entrepreneurs in the entrepreneurial network together in a coalition for ideational and policy change. Without a political entrepreneur to inject new ideas into the policy making arena, third order/paradigm change (Hall 1993) will not occur, as no agents within the entrepreneurial network possess the necessary access to existing institutional arrangements to implement such change. Instead, there may be a first order policy change (change to the policy instrument settings), or a second order policy change (change to the setting and instruments of policy). Consequently:

Hypothesis 3: Third order (paradigmatic) policy change will result if a political entrepreneur injects the ideas espoused by an entrepreneurial network into the political environment.

While policy networks constitute a particularly important intermediate variable in enabling policy change (Pemberton 2000), the political entrepreneur is the "crucial element."

\section{Methods and Country Selection}

Comparative historical analysis has sought to provide temporally grounded accounts of diverse topics in the social sciences, including accounts of policy change. This approach is "defined by a concern with the use of systematic and contextualized comparison" (Mahoney and Rueschemeyer 2003, 3). By examining the nature of economic policy change at the national level in two countries, namely Sweden and the United States (US), this paper seeks to add to the extant literature, which is mostly made up of individual country examinations that often juxtapose different levels of policy change (Howlett and Cashore 2009). 
Sweden in the mid 1970s and the US at the beginning of the 1980s constitute interesting cases. Each country appeared to have reached a turning point in their histories at these times. In Sweden, the years immediately following the oil crisis of the early 1970s were marked by both recession and stagflation as the economy struggled to maintain the welfare state (OECD 1978). In a context of declining economic competiveness, rising unemployment, and a widening budget deficit, there were worries that the Swedish Model of free enterprise coexisting with an expansive welfare state could no longer survive (Fulcher 1991; Mjoset 1992). By the early 1980s, the US was locked in economic stagnation (Dark 2001). Stagflation led to a deep soul searching as to the country's economic future (Divine et al. 1995). There was a sense that the federal government lacked an understanding of how this problem might be resolved (Spulber 1995).

In both countries there was deep anxiety - a questioning of past decisions married with uncertainty as to how to proceed. In a sense, they were experiencing existential angst. To many Swedes, the Swedish Model appeared unsustainable by the mid-1970s, while, for Americans, the central tenets of the American Dream seemed to have foundered.

In addition to being selected for having reached a crossroads in their development, the countries were selected using a combination of most-similar and most different criteria. Using the most similar case selection method, the same independent variables are chosen; when employing the most different technique, dissimilar independent variables are selected (Gerring 2007). The US and Sweden share the overarching criteria of being long-standing democracies and capitalist states. The specific criteria were 1) stable democracy since the first half of the twentieth century and 2) founding membership of the Organisation for Economic Cooperation and Development (OECD), conditions uniting the principles of representative democracy and the free market. Thus, we are examining the nature of macroeconomic policy change within the context of different temporal boundaries (Gerring 2007) at the national level. These countries are most different according to Lijphart's (1999) categories of majoritarian and consensual democracies, allowing us to control for varying institutional arrangements. Additionally, while the US is a federal presidential republic, Sweden is a constitutional monarchy. Both countries' economies' performances, and the policies governing them, varied during the $20^{\text {th }}$ century.

The similarities ensure that "the contexts of analysis are analytically equivalent," while their differences place "parallel processes of change in sharp relief" (Collier 1997, 4). The value of such cross national studies, historical in context, is that they offer the prospect of conceptual breakthroughs in our understanding of policy change (Lieberman 2001). 
Hogan and Feeney: Crisis and Policy Change

\section{Evaluation and Discussion}

\section{Sweden, 1976}

The Economic Crisis. By the 1970s, Sweden was straining under the burden of supporting its welfare state (Time 1976a). Increased international competition, stagnating demand, and recession following the oil crisis of 1973 led to decline in the steel and shipbuilding industries (Lundberg 1982). The industrial sector shrank relative to other parts of the economy. Annual productivity growth, having increased at 4.1 percent per year between 1950 and 1973, dropped to 1.4 percent thereafter (Forseback 1976). The public sector's share of GDP rose and the number of public sector jobs, increased to maintain the image of full employment, came to outnumber those in private industry after 1978 (Gress 1991; OECD 1992). Lindbeck (1997) argues that sluggish productivity growth was, to some extent, the result of the increasing size of public sector.

By 1976, most economic indicators were pointing downwards. Sweden's unemployment rate averaged 2 percent during the 1970s, double that experienced in the 1960s (OECD 1977). "But the maintenance of high employment had been accompanied by less favourable performance in other areas, notably costs, prices and the balance of payments" (OECD 1977, 42). Inflation was double that of the previous decade, with the oil crisis contributing to prices' upward trajectory. "In the 1970s, wages exploded in a self-destructive series of agreements that placed Swedish firms in the un-competitive position of having the highest paid labour force in the world" (Ahlén 1989, 333). The balance of payments also deteriorated sharply (OECD 1976). The economy's growth slowed to 1 percent in 1976 from 2.5 percent the previous year before contracting in 1977 (O'Connor, O'Malley, and Foley 1978). The government's purist counter-cyclical fiscal policies resulted in the budget deficit expanding significantly (Siven 1984), with the national debt tripling within a decade (OECD 1982a).

Extant Ideational Collapse. During the 1970s, elections were dominated by concerns over social welfare, employment, taxation, and nuclear power. As the 1976 general election approached, the Social Democratic Workers' Party, Socialdemokratiska Arbetarepartiet (SAP) noted declining support (Hadenius 1997). The previous three years had been marked by parliamentary deadlock due to a close 1973 election. In 1976, the Swedish Trade Union Confederation, Landsorganisationen $i$ Sverige (LO), proposed a wage earner fund, through a levy on corporate profits, to transfer control of enterprises with more than 50 employees to the unions (Esping-Andersen 1992). However, the SAP retreated from the idea due to the opposition of the Swedish Employers' Federation, Svenska Arbetsgivarforening (SAF) (Whyman and Burkitt 1993). The non- 
socialist parties, "at last with an issue around which they could collectively mobilise," argued that the wage earner fund proposal demonstrated the SAP wanted state dominance in the business sector, whereas the Swedish model had been built on co-operation of both sides of industry with a neutral state (Blyth 2002 , 207). The unions seemed to be moving further to the left, away from an accommodation with capitalism and towards outright socialism, while their political allies in the SAP were shifting to towards the center. The SAP was also criticised from the left by the Left Party Communists, Vänsterpartiet Kommunisterna (VPK), due to unprecedented unrest in the labour market. This situation, rife with unfulfilled economic expectations and change agents dissatisfied with the prevailing circumstances and paradigm, constituted ideational collapse.

The Failure of New Ideational Consolidation. The deadlock in Parliament between the 1973 and 1976 elections created political uncertainty, while the three non-socialist parties (Centre, Liberal, and Moderate) became more skilled at presenting a united front in election campaigns and Parliament (Time 1976b). The 1976 election campaign saw the non-socialist parties unite under the leadership of Thorbjörn Fälldin of the Centre Party (Back et al. 2009). Fälldin depicted the SAP government as advocates of an unwieldy, inhumane society that accorded higher priority to growth and profitability than to other, more important values, such as the environment and individual freedom. Time (1976b) pointed out that the growing concentration of state power and fear of the overbureaucratisation of society through the wage earner funds were the nonsocialists' targets. This election, resulting in only small shifts in the relative strength of the socialist and non-socialist blocs, saw the defeat of the SAP after having ruled Sweden for 44 years (Hinnsfors 2006). The combination of the Centre, Liberal, and Moderate parties won a five seat majority in parliament. "The Swedish model has gone in for repair," proclaimed the Financial Times (Garme 2001, 133).

The discussions surrounding the election and economy did not result in the emergence of alternative economic ideas to the existing ones, or a significant change agent - a political entrepreneur. The SAF acted as a policy entrepreneur to the extent that it sought to stop wage earner funds, but that was all. No other significant policy entrepreneurs were present. No political leader was prepared to advocate an alternative to, or an end to, social democracy. The non-socialists had been out of power for almost half a century, so the last thing they wanted was to dismantle the welfare state built up by the LO and SAP, for fear of another half century in opposition. Thus, in spite of the dominant economic orthodoxy's failure to meet the challenges of the post oil crises world, the non-socialist parties proved both unwilling and unable to create a coalition around alternative ideas to 
social democracy. They wanted to show the public that the welfare state was safe with them.

First Order Policy Change. The SAP's election defeat only resulted in what could best be described as "business as usual" for the welfare state. The new Prime Minister Thorbjörn Fälldin, in order to form a coalition out of the non-socialist parties, backed away from anything that might generate controversy (Arter 2006). For instance, his re-election promise to rapidly dismantle nuclear power plants was shelved (Larsson, Letell, and Thörn 2012), as both the Liberals and Moderates supported the construction of more such facilities (Time 1976a). Such constraints on the ability to implement election promises had severe consequences for the government's lifespan. Ironically, there followed, under the non-socialists, an expansion in spending to reanimate the sluggish economy, as well as increases in sick pay, funding for child-care centres, and food subsidies (Ginsburg and Rosenthal 2002).

Nevertheless, the employers, encouraged by the SAP's defeat, launched an ideological and political counter-offensive against the trade union movement (Whyman and Burkitt 1993). In contrast to the 1930s, the balance of power gradually shifted in the SAF's favour. However, no change to the social democratic nature of the state occurred after 1976. When the non-socialists came to power they attempted to demonstrate that they were not aiming at counterrevolution and would not be tampering with the country's well developed welfare system (Childs 2000). Fälldin assured Swedes that he had no intention of repealing any of their social benefits, and instead promised to try and better them (Hadenius 1997). The new government continued to consult regularly with the union movement, and the LO's representation on government committees and commissions was the same after 1976 as before. But, Fälldin did interpret the election as a mandate to break the concentration of power in the state's bureaucracy and to halt experimentation with new social programs.

The new administration, eager to prove it would not wreck the welfare state, took measures to ease the structural problems industry faced. Certain firms in difficulty were nationalised while others received subsidies (O'Connor, O'Malley and Foley 1978). The support of employment in iron ore, steel, and shipbuilding meant preservation of inappropriate structures of production. Unemployment also continued to be concealed by expanding public works, training programs, and the public sector (Statistisk Arsbok 1982-83). "The results were predictable, the budget and external current account went deep into deficit, and inflation rose" (Delsen and van Veen 1992, 94).

After two years trying to find a solution to Sweden's nuclear power issues, the Fälldin government resigned. It was replaced by a Liberal minority government, with Ola Ullsten as prime minister. This government lasted for just 
under a year. The 1979 general election saw the non-socialist parties take 49 percent of the vote and win the election by just one seat. Thorbjorn Fälldin returned as prime minister. However, on many issues the non-socialists remained divided (Peterson 1987). Consequently, the coalition could not agree on a set of policies to counteract the deteriorating economic situation (Olsen 1984). Not only were they unable to make significant reductions in public expenditure, but their rule coincided with a particularly difficult time for the economy. The irony was that the right wing administrations had nationalised and subsidised weak industries, something the SAP had resisted (OECD 1978). This failure to improve the economy led to disenchantment amongst the electorate. All the non-socialist governments seemed to want was to maintain social democracy by whatever means necessary (Callaghan 2000).

In this case, economic policy instrument settings changed (first order policy change), but the instruments of economic policy, and the goals behind it, remained much the same (Hall 1993). Table 1 summarizes the case study's fit with the hypotheses.

Table 1. Empirical Theoretical Fit for Sweden, 1976

\begin{tabular}{|l|c|}
\hline Hypothesis & Evaluation \\
\hline Hypothesis 1: Crisis to Initiate Debate Concerning Extant Policy & No \\
\hline $\begin{array}{l}\text { Hypothesis 2: Ideational Change (Extant Ideational Collapse and New } \\
\text { Ideational Consolidation) }\end{array}$ & No \\
\hline Hypothesis 3: Third Order Policy Change &
\end{tabular}

The economic crisis in Sweden failed to generate a significant level of debate on alternatives to social democracy. While extant economic policy was perceived as failing, change agents did not consolidate around a replacement orthodoxy. This was primarily due to the absence of policy entrepreneurs putting forward alternative ideas to social democracy and a political entrepreneur willing to champion alternative ideas in the policy making environment (Figure 2). Despite an economic crisis, criticisms of social democratic policies and their underlying theories, and a change of government from SAP to a liberal coalition, this orthodoxy endured. No political party leader, nor party, was willing to take on this pillar of Swedish society for fear of electoral suicide. "Apart from disavowing wage earner funds, the bourgeois parties offered no real alternative to SAP policies" (Blyth 2002, 207). Ironically, the non-socialist coalitions went further than the SAP in supporting industries in difficulty and ultimately failed to adjust the expectations of the electorate to Sweden's straitened circumstances (Arter 2006). 


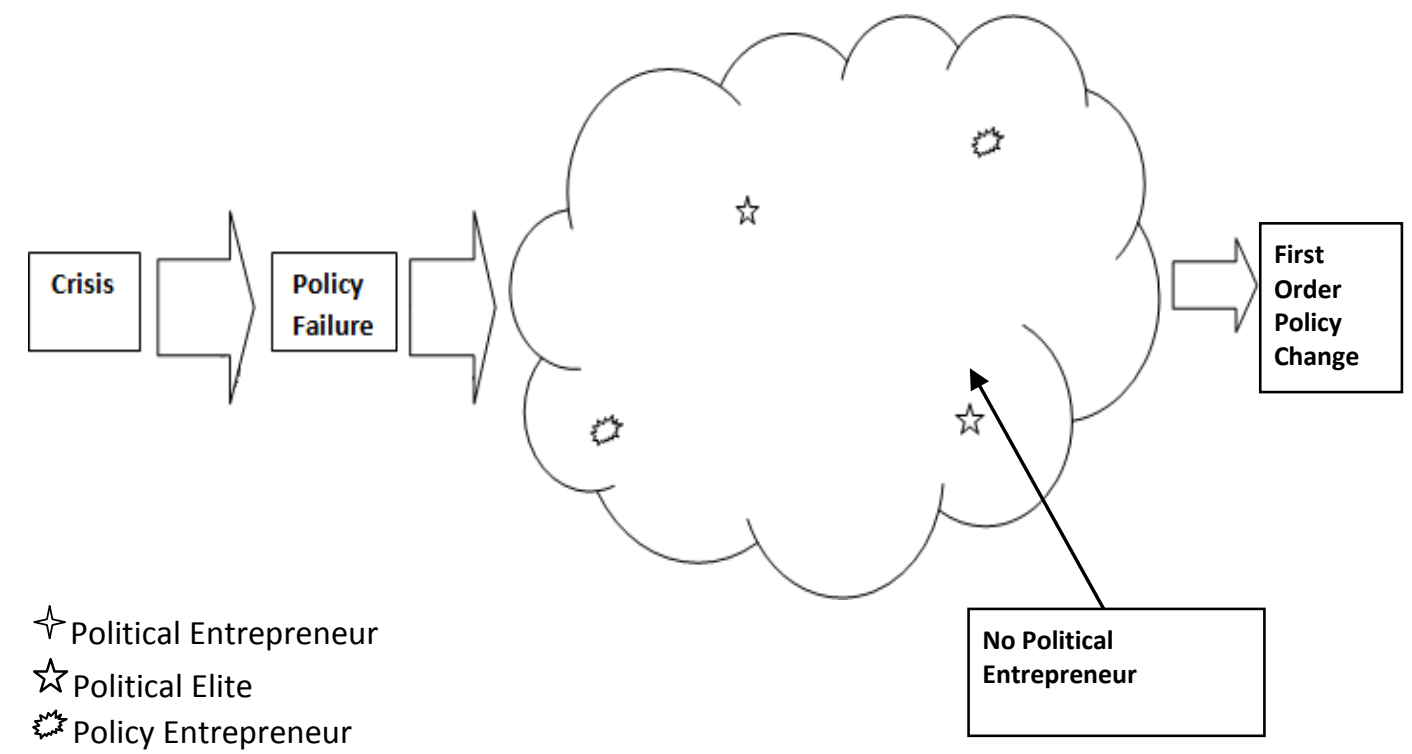

Figure 2. The Absence of Political Entrepreneurs in Sweden, 1976

\section{The United State of America, 1980/1981}

The Economic Crisis. The last year of President Carter's administration was marked by rising unemployment and high interest rates (OECD 1982b). "Washingtonians joked that [Carter] was the first President with poll ratings lower than the prime interest rate" (Boller 1996, 355). The president's implementation of the Credit Control Act had the effect of reducing borrowing and putting a dampener on economic growth (Hall 2003). By 1980 inflation reached 13.5 percent, its highest level since 1946, while GDP growth contracted (Mitchell 1998). The nonpartisan National Bureau of Economic Research (NBER), with a reputation for declaring when recessions start and finish, announced that the US economy was in recession (Time 1980a). The Economic Report of the President 1981 showed an administration ready to "throw in the towel" on the economy (Spulber 1995, 41). There was criticism of Carter's plans to stimulate the economy (Biven 2002). "Too little, too late, too political," complained Murray Weidenbaum of Washington University, providing "the opposite of what the ailing economy needs" (Time 1980b, 34). Teaster (2004) points out that by late autumn Federal Reserve Chairman Paul Volcker acknowledged that the economy was in recession. The problem was that the Fed, in tightly controlling the money supply, caused interest rates to reach their highest levels in a century. The effect was to reduce borrowing and send spending into decline (Weidenbaum 2011). Thus, the combined actions of the Federal Reserve and the White House plunged the economy into the recession that they had both been trying to avoid (Dark 
2001). Volcker's advocacy of a tightened money supply in order to reduce inflation constituted a move towards monetarist policy (Krugman 1990). However, the American public was very dissatisfied with the government's performance.

Extant Ideational Collapse. The president's policies to reduce inflation, intended to revive the economy and ensure his re-election, instead contributed to reduced consumer borrowing, economic stagnation and his subsequent election defeat (Sherman et al. 2008). The news media, such as the Washington Post, began to openly declare that the economy was in a serious recession (Hargrove 1988). Economists were generally of the opinion that there was little likelihood of an economic recovery in the medium term. "The great stagflation swamp" was how Walter Okun (1997) termed the situation. Alan Greenspan, a future chairman of the Federal Reserve, observed that, as a consequence of the economy's stagnation, President Carter found himself forced into an emergency program of restraint, leading to a rapid rise in unemployment (Bilhartz and Elliott 2007). A result of this situation was that economists, and other policy entrepreneurs, began to gradually advocate a paradigm that they believed was capable of correcting the problems in the economy: monetarism.

Various conservative think tanks, such as the American Enterprise Institute (AEI) - a strong proponent of the free market since the late 1930s, had been advocating monetarist ideas, as had economists such as Milton Friedman, Karl Brunner of the University of Rochester, Arthur Laffer, Alan Meltzer of Carnegie Mellon University, Robert Lucas, and the economic staff of the Federal Reserve Bank of St. Louis (Blyth 1997; Weidenbaum 2011). Institutions and economists of this perspective worked hard to ensure that economic journalism in the media, for example in newspapers such as the Wall Street Journal, served as a conduit for their ideas (Blyth 1997). The late 1970s also saw a group of mostly Republican Congressmen and staffers advocating what became known as supply side economics (Hogan 1990a). With policy entrepreneurs generally in agreement as to the inadequacy of the extant paradigm, ideational collapse had occurred.

New Ideational Consolidation. The Republicans nominated Ronald Reagan as their candidate for President. Adopting the role of a political entrepreneur, he embraced the ideology of the New Right - a cultural conservatism stressing social and moral issues, and advocating supply side economics. His campaign was to be change orientated. This was emphasized in a campaign speech in Chicago advocating the Kemp-Roth economic formula (Hogan 1990a). He had a simple message: low taxes, reduced spending on social services, balanced budgets, and fewer government regulations. Advocacy of supply side economics fit particularly well with Reagan's view that the citizens could resolve the country's problems if 
there was less governmental interference in their lives (Wallison 2003). Reagan urged a bold program of tax reductions, spending restraints, and regulatory reforms that would inject new life into the economy (Hogan 1990b). Where Barry Goldwater had failed in 1964, Reagan was convinced he could triumph in 1980 (Hirsh 2010).

Reagan laid the blame for the recession at the door of the president, saying that Carter's policies had stifled productivity while increasing both inflation and unemployment (Hirsh 2010). Reagan succeeded in building an electoral coalition around the concept of monetarism and won the 1980 presidential election on the back of advocating a marked set of alternative economic ideas which could used to supplant extant arrangements (Blyth 1997). Reagan's election victory, and the Republicans' regaining of control of the Senate for the first time since 1954, were seen as providing a mandate for monetarist policies (OECD 1982b). In the midst of an economic crisis there was a collapse in confidence in the dominant economic orthodoxy. Various economists, think tanks, and other interest groups, acting as policy entrepreneurs and advocating monetarist economic ideas, consolidated around Reagan in the role of a political entrepreneur. This acceptance of monetarism as a viable alternative orthodoxy constituted ideational change.

Several economic, ideological, and social trends contributed to Reagan's appeal. The 1970s witnessed growing middle class opposition to the taxes necessary to sustain programs such as social security. This burden became greater as the economic depression deepened, leading to a questioning of existing policies and their underlying ideas.

Third Order Policy Change. Reagan utilized anti-government sentiment to his advantage, emphasizing the importance of individualism and a smaller role for the federal government. The monetarist proposals of policy entrepreneur Arthur Laffer played a large role in Reagan's economic strategy. For the problem of stagflation he promoted a seemingly straightforward remedy: tax cuts, wherein the resulting stimulus would boost the federal government's revenues to balance the budget, consequently reducing inflationary pressure (Dallek 1984). Reagan's uncomplicated patriotism acted as a balm to the wounded national psyche. However, the victory of New Conservatism was also driven by the challenge to America's economic hegemony by West Germany and Japan (Renshaw 1991). President Reagan's new economic program, dubbed Reaganomics by the media, was built upon the belief that reductions in regulations and taxes would allow the economy to rebound. Thus, new economic policies were drawn along lines that were very different from those of preceding governments in their theoretical and political origins (OECD 1982b). 
The first budget the new president sent to Congress proposed a $\$ 750$ billion tax cut, built around a 30 percent reduction in federal income tax over three years (Jones 1995). It was bold and original, the largest tax reduction in US history (Peterson and Rom 1988). The administration also reduced spending on unemployment benefits programs, job training programs, public works and trade adjustment assistance benefits by $\$ 11$ billion (Jones 1995). These were all moves advocated by David Stockman at the Office of Management and Budget as a means of cutting taxes, increasing defense expenditure, and balancing the budget (Peele 1990). For Stockman this marked a clear break with past policy (Stockman 1981). Middle and working class Americans, who had organised "tax revolts" from Massachusetts to California, applauded this policy (Jones 1995).

The new administration sought to reduce regulation across the economy and towards that end it abolished the Council on Wage and Price Stability (OECD 1982b). Following Reagan's election, economic policy instrument settings, the instruments of economic policy, and the hierarchy of goals behind economic policy all changed. This transformation in economic policy endured into the administrations of Reagan's successors. As such, D'Souza (1997) regards Reagan's program for the economy as the most ambitious in the half century following the Great Depression.

Wallison (2003) argues that Reagan, coming as he did with a fully developed philosophy of government, represented a set of ideas that reformulated Republican policy to tap into traditional American values - private sector based economic growth and individual opportunity. In addition to reorienting the GOP, he persuaded Americans that there was another way to think about their economy and government. This resulted in the radical shift in economic policy that lay at the heart of the "Reagan Revolution" (Weatherford and McDonnell 2005). For Wallison (2003) this marked a historic turning point in the US, even arguing that the Republicans' 1994 takeover of Congress was largely based on Reagan's enduring ideas. Reagan's economic policies changed the economic and political landscape of 1980s America, and an examination of the 1990s shows that the thrust of these policies remained essentially intact over a decade later (Busch 2005). Table 2 summarizes the case study's fit with the hypotheses.

Table 2. Empirical Theoretical Fit for the US, 1980/1981

\begin{tabular}{|l|c|}
\hline Hypothesis & Evaluation \\
\hline Hypothesis 1: Crisis to Initiate Debate Concerning Extant Policy & Yes \\
\hline $\begin{array}{l}\text { Hypothesis 2: Ideational Change (Extant Ideational Collapse and New } \\
\text { Ideational Consolidation) }\end{array}$ & Yes \\
\hline Hypothesis 3: Third Order Policy Change & Yes \\
\hline
\end{tabular}


A severe economic crisis led policy entrepreneurs and outside influences to contest the viability of extant economic policies. These attacks on extant policy led to the collapse of the ideas underlying it. In this environment, an entrepreneurial network of policy entrepreneurs advocated a replacement set of ideas: monetarism. Political entrepreneur Ronald Reagan, willing to promote monetarism as an alternative approach to running the economy, managed to consolidate the entrepreneurial network advocating this new economic orthodoxy, resulting in ideational change. Following Reagan's election as president he implemented a third order change (paradigm shift) (see Figure 3) in macroeconomic policy (Hall 1993). Thus, a macro-economic crisis, the initiation of a policy debate, ideational change, and a change of government, all contributed to the paradigm shift in economic policy that took place in America after 1981. However, the crucial element was Ronald Reagan. Acting as the archetypal political entrepreneur, after consolidating policy entrepreneurs around a new economic ideational structure, he was willing to champion those ideas once in power, injecting them into the political environment. This led directly to a radical change in macro-economic policy.

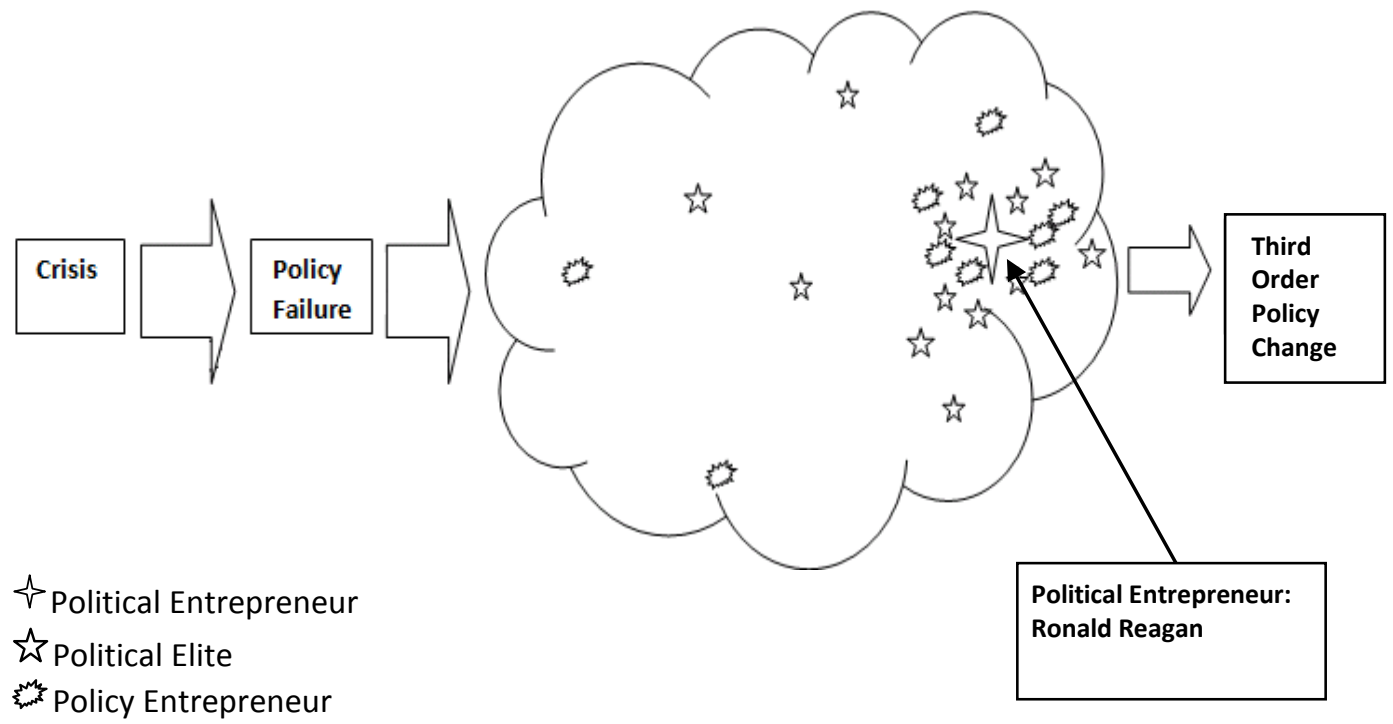

Figure 3. The Presence of a Political Entrepreneur in the US, 1980/1981

\section{Conclusion}

This paper sought to uncover the inner mechanisms of policy change and, specifically, how ideas enter the political arena to enact change. We argue that 
reliance on exogenous shocks to account for policy change is too simplistic and fails to explain the absence of change in the wake of a crisis. The central thesis was that the introduction of new ideas into the policy environment, and their transformation into policy, was due to the activities of "entrepreneurial networks" of policy entrepreneurs, with political entrepreneurs at their head. The entrepreneurial network is, as Schumpeter (1934) argued in relation to economic entrepreneurs, a vibrant endogenous driver of creative destruction, where new policies are formed to replace old and failing ones.

The cases examined were Sweden in the mid 1970s and the US at the start of the 1980s. In each case there was economic crisis, criticisms of existing economic policy, resultant policy debates, and changes of government and political leaders. In the case of Sweden, there was no economic ideational change, whereas in the US there was. While ideational collapse occurred in Sweden, policy entrepreneurs, lacking a political entrepreneur, failed to consolidate around a viable alternative idea. Without ideational change, there was only minor policy change. In the US, ideational collapse was followed by ideational change and, subsequently, third order policy change, as an entrepreneurial network of policy entrepreneurs, all advocating monetarism, consolidated around a political entrepreneur in the form of Ronald Reagan. The difference between the level of economic policy change in the US on the one hand and Sweden on the other was due to the presence of an entrepreneurial network and a political entrepreneur.

In Sweden, the intermediary necessary to bridge the gap between the ideas of policy entrepreneurs and the political institutions was missing. While an economic crisis initiated debate on existing economic policies and their underlying ideas, this crisis did not result in policy change. Policy change remains firmly dependent upon political entrepreneur led entrepreneurial networks consolidating around new economic ideas, which the political entrepreneur then introduces to the institutional environment. The political entrepreneur is the primary and endogenous force responsible for policy change.

However, a limitation of this paper is that the framework set out here is tested within relatively stable political/policy systems, into which political entrepreneurs can inject new ideas. An alternative would be to test this framework in the context of institutional instability, wherein the political entrepreneur might not be an endogenous entity. Such an examination would test the limitations of the framework's hypotheses, allowing for their modification and the strengthening of the framework. 
Hogan and Feeney: Crisis and Policy Change

\section{References}

Ahlén, Kristina. 1989. "Swedish Collective Bargaining Under Pressure: Interunion Rivalry and Incomes Policies." British Journal of Industrial Relations, 23 (3): 330-346.

Arter, David. 2006. Democracy in Scandinavia: Consensual, Majoritarian or Mixed? Manchester: Manchester University Press.

Back, Hanna, Thomas Persson, Kare Venbu, and Helena Wockelberg. 2009. "In Tranquil Waters: Swedish Cabinet Ministers in The Postwar Era." In The Selection of Ministers in Europe, eds. Keith Dowding and Patrick Dumont. Abingdon: Routledge.

Berman, Sheri. 1998. The Social Democratic Moment: Ideas and Politics in the Making of Interwar Europe. Cambridge MA: Harvard University Press.

Bilhartz, Terry D., and Alan C. Elliott. 2007. Currents in American History: A Brief History of the United States. New York, NY: M E Sharp, Inc.

Biven, W. Carl. 2002. Jimmy Carter's Economy: Policy in an Age of Limits. Chapel Hill, NC: University of North Carolina Press.

Blundell, John. 2008. Margaret Thatcher: A Portrait of the Iron Lady. New York, NY: Algora Publishing.

Blyth, Mark. 1997. "Moving the Political Middle: Redefining the Boundaries of State Action." The Political Quarterly 68 (3): 217-314.

Blyth, Mark. 2002. Great Transformations: Economic Ideas and Institutional Change in the Twentieth Century. Cambridge: Cambridge University Press.

Boller, Paul F. 1996. Presidential Campaigns. Oxford: Oxford University Press.

Busch, Andrew E. 2005. "Ronald Reagan and Economic Policy." In The Reagan Presidency: Assessing the Man and His Legacy, eds. Paul Kengor and Peter Schweizer. Oxford: Rowman and Littlefield Publishers, 25-46.

Callaghan, J. 2000. The Retreat of Social Democracy. Manchester: Manchester University Press.

Childs, David. 2000. The Two Red Flags: European Social Democracy and Soviet Communism since 1945. London: Routledge.

Collier, David. 1997. "Comparative Method in the 1990s." APSA-CP: Newsletter of the APSA Organised Section in Comparative Politics 9 (1): 1-5.

Collier, Ruth. B., and David Collier. 1991. Shaping the Political Arena: Critical Junctures, the Labour Movement, and Regime Dynamics in Latin America. Princeton, NJ: Princeton University Press.

Dahl, Robert. 1961. Who Governs? Democracy and Power in an American City. New Haven, CT: Yale University Press.

Dallek, Robert. 1984. Ronald Reagan: The Politics of Symbolism. Cambridge, MA: Harvard University Press. 
Dark, Taylor E. 2001. The Unions and the Democrats: An Enduring Alliance. London: Ithaca.

Delsen, Lei, and Tom van Veen. 1992. "The Swedish Mode: Relevant for Other European Countries?" British Journal of Industrial Relations 30 (1): 83105.

Divine, Robert A., T. H. Breen, George M. Fredrickson, R. Hal Williams, and Randy Roberts. 1995. America Past and Present. $4^{\text {th }}$ ed. New York, NY: HarperCollins.

D’Souza, Dinesh. 1997. Ronald Reagan: How an Ordinary Man Became an Extraordinary Leader. New York, NY: The Free Press.

Esping-Andersen, Gosta. 1992. "The Making of a Social Democratic Welfare State." In Creating Social Democracy: A Century of the Social Democratic Labour Party in Sweden, eds. Klaus Misgeld, Karl Molin and Klas Amark. Pennsylvania: Pennsylvania State University, 35-61.

Forseback, Lennart. 1976. Industrial Relations and Employment in Sweden. Stockholm: The Swedish Institute.

Fulcher, James. 1991. Labour Movements, Employers and the State. Oxford: Clarendon Press.

Garme, Cecilia. 2001. Newcomers to Power: How to Sit on Someone Else's Throne. Uppsala: Uppsala Universitet.

Garrett, Geoffrey. 1993. "The Politics of Structural Change: Swedish Social Democracy and Thatcherism in Comparative Perspective." Comparative Political Studies 25 (4): 521-547.

Gerring, John. 2007. Case Study Research: Principles and Practices. Cambridge: Cambridge University Press.

Ginsburg, Helen Lachs, and Marguerite G. Rosenthal. 2002. "Sweden: Temporary Detour or New Directions?" In A Cross-National Study of Social Provision, eds. Gertrude Schaffner Goldberg and Marguerite G. Rosenthal. Westport, CT: Greenwood Publishing Group, Inc., 103-148.

Gress, David. 1991. "The Nordic Countries." In Politics in Western Europe, eds. Gerald A. Dorfman and Peter J. Duignan. Stanford, CA: Hoover Press, 122-168.

Golob, Stephanie. 2003. "Beyond the Policy Frontier: Canada, Mexico, and the Ideological Origins of NAFTA." World Politics 55 (3): 361-398.

Gorges, M. J. 2001. "The New Institutionalism and the Study of the European Union: The Case of the Social Dialogue." West European Politics 24 (4): $152-168$.

Gould, Stephen Jay, and Niles Eldredge. 1977. "Punctuated Equilibria: The Tempo and Mode of Evolution Reconsidered." Paleobiology 3 (2): 115151. 
Hogan and Feeney: Crisis and Policy Change

Greener, Ian. 2001. "Social Learning and Macroeconomic Policy in Britain." Journal of Public Policy 21 (2): 133-152.

Hadenius, Stig. 1997. Swedish Politics during the $20^{\text {th }}$ Century - Conflict and Consensus. Stockholm: Svenska Institute.

Hall, Peter. A. 1993. "Policy Paradigms, Social Learning, and the State: The Case of Economic Policy Making in Britain." Comparative Politics 25 (3): 275296.

Hall, Thomas E. 2003. The Rotten Fruits of Economic Controls and the Rise from the Ashes, 1965-1989. Lanham, MD: University Press of America.

Hargrove, Erwin C. 1988. Jimmy Carter as President: Leadership and Politics of the Public Good. Lousiana State University: Lousiana State University Press.

Hay, Colin. 1999. "Crisis and the Structural Transformation of the State: Interrogating the Process of Change." The British Journal of Politics and International Relations 1 (3): 317-344.

Hay, Colin. 2004. "Ideas, Interests and Institutions in the Comparative Economy of Great Transformations." Review of International Political Economy 2 (1): 204-26.

Hinnsfors, Jonas. 2006. Reinterpreting Social Demcracy: A History of Stability in the British Labour Party and Swedish Social Democratic Party. Manchester: Manchester University Press.

Hirsh, Michael. 2010. Capital Offense: How Washington's Wise Men Turned America's Future Over to Wall Street. Hoboken, NJ: John Wiley \& Sons.

Hogan, Joseph J. 1990a. "Reaganomics and Economic Policy." In The Reagan Presidency: An Incomplete Revolution?, eds. Dilys M. Hill, Raymond A. Moore and Phil Williams. London: Macmillan, 198-213.

Hogan, Joseph J. 1990b. "The Federal Budget in the Reagan Era." In The Reagan Years: The Record in Presidential Leadership, ed. Joseph Hogan. Manchester: Manchester University Press, 214-236.

Howlett, Michael, and Benjamin Cashore. 2009. "The Dependent Variable Problem in the Study of Policy Change: Understanding Policy Change as a Methodological Problem." Journal of Comparative Policy Analysis: Research and Practice 11 (1): 33-46.

Hwang, Hokyu, and Walter Powell. 2005. "Institutions and Entrepreneurship." In Handbook of Entrepreneurship Research: Disciplinary Perspectives, eds. Sharon A. Alvarez, Rajshree R. Agarwal and Olav Sorenson. New York, NY: Springer, 201-232.

Jones, Maldwyn A. 1995. The Limits of Liberty: American History 1607 - 1992. $2^{\text {nd }}$ ed. Oxford: Oxford University Press.

Kingdon, John. W. 1995. Agendas, Alternatives, and Public Policy. $2^{\text {nd }}$ ed. New York, NY: Harper. 
Krugman, Paul A. 1990. The Age of Diminished Expectations: US Economic Policy in the 1990s. Cambridge, MA: MIT Press.

Larsson, Bengt, Martin Letell, and Hakan Thörn. 2012. Transformations of the Swedish Welfare State: From Social Engineering to Governance. London: Palgrave Macmillan.

Legro, Jeffrey. W. 2000. "The Transformation of Policy Ideas." American Journal of Political Science 44 (3): 419-432.

Levy, Jack S. 1994. "Learning and Forign Policy: Sweeping a Conceptual Minefield." International Organization 48 (3): 279-312.

Lieberman, Evan. S. 2001. "Causal Inference in Historical Institutional Analysis: A Specification of Periodization Strategies." Comparative Political Studies 34 (9): 1011-1035.

Lijphart, Arend. 1999. Patterns of Democracy: Government Forms and Performance in Thirty-six Countries. New Haven, CT: Yale University Press.

Lindbeck, Assar. 1997. "The Swedish Experiment." Journal of Economic Literature 35 (3): 1273-1319.

Lundberg, Erik. 1982. "The Rise and Fall of the Swedish Model." In Europe's Economy in Crisis, ed. Ralf Dahrendorf. New York, NY: Holmes \& Meier, 195-211.

Mahoney, James. 2001. "Path Dependent Explanations of Regime Change: Central America in Comparative Perspective." Studies in Comparative International Development 36 (1): 111-141.

Mahoney, James, and Dietrich Rueschemeyer. 2003. "Comparative Historical Analysis: Achievements and Agendas." In Comparative Historical Analysis in the Social Sciences, eds. James Mahoney and Dietrich Rueschemeyer. Cambridge: Cambridge University Press, 3-40.

McCaffrey, Matthew, and Joseph T. Salerno. 2011. "A Theory of Political Entrepreneurship." Modern Economy 2 (4): 552-560.

Mintrom, Michael, and Phillipa Norman. 2009. "Policy Entrepreneurship and Policy Change.” Policy Studies Journal 37 (4): 649-67.

Mitchell, Brian R. 1998. International Historical Statistics: The Americas 17501993. 4th ed. Basingstoke: Macmillan.

Mjoset, Lars. 1992. The Irish Economy in a Comparative Institutional Perspective. Dublin: NESC.

O'Connor, Robert, Eoin O'Malley and Anthony Foley. 1978. Aspects of the Swedish Economy and their Relevance to Ireland. Dublin: Economic and Social Research Institute.

Okun, Walter. 1977. "The Great Stagflation Swamp (Remedies)." Challenge 20 (November/December). 
Hogan and Feeney: Crisis and Policy Change

Oliver, Michael J. 1997. Whatever Happened to Monetarism? Economic Policymaking and Social Learning in the United Kingdom since 1979. Burlington, VT: Ashgate.

Oliver, Michael J., and Hugh Pemberton. 2004. "Learning and Change in 20thCentury British Economic Policy.” Governance 17 (3): 415-441.

Olsen, Erling. 1984. "The Dilemma of the Social Democratic Labour Parties." Daedalus 113 (4): 169-194.

Organisation for Economic Cooperation and Development. 1976. Sweden 1976. Paris: OECD.

Organisation for Economic Cooperation and Development. 1977. Sweden 1977. Paris: OECD.

Organisation for Economic Cooperation and Development. 1978. Sweden 1978. Paris: OECD.

Organisation for Economic Cooperation and Development. 1982a. Sweden 1982. Paris: OECD.

Organisation for Economic Cooperation and Development. 1982b. The United States of America 1982. Paris: OECD.

Organisation for Economic Cooperation and Development. 1992. Sweden 1992. Paris: OECD.

Orren, Karen, and Stephen Skowronek. 1994. "Beyond the Iconography of Order: Notes for a 'New Institutionalism.'” In Dynamics of American Politics: Approaches and Interpretations, eds. Lawrence C. Dodd and Calvin Jillison. Boulder, CO: Westview Press, 311-330.

Peele, Gillian. 1990. "The Agenda of the New Right.” In The Reagan Presidency: An Incomplete Revolution?, eds. Dilys M. Hill, Raymond A. Moore and Phil Williams. London: Macmillan, 29-47.

Pemberton, Hugh. 2000. "Policy Networks and Policy Learning: UK Economic Policy in the 1960s and 1970s." Public Administration 78 (4): 771-792.

Peterson, Richard B. 1987. "Swedish Collective Bargaining - A Changing Scene.” British Journal of Industrial Relations 25 (1): 31-48.

Peterson, Paul E., and Mark Rom. 1988. "Lower Taxes, More Spending, and Budget Deficits." In The Reagan Legacy, ed. Charles O. Jones. New Jersey: Chatham House Publishing, 218-221.

Renshaw, Patrick. 1991. American Labour and Consensus Capitalism, 19351990. London: Macmillan Education Limited.

Schumpeter, Joseph A. 1934. The Theory of Economic Development. Cambridge, MA: Harvard University Press.

Sheingate, Adam. D. 2003 "Political Entrepreneurship, Institutional Change, and American Political Development." Studies in American Political Development 17 (3): 185-203. 
Sherman, Howard J., E. Hunt, Reynold F. Nesiba, Philip A. O'Hara, and Barbara Wiens-Tuers. 2008. Economics: An Introduction to Traditional and Progressive Views. 7th ed. New York, NY: M. E. Sharpe.

Siven, Claes-Henric. 1984. "The Political Economy of Sweden in the 1970s." Department of Economics - University of Stockholm, Research Papers in Economics, No. 1.

Spulber, Nicolas. 1995. The American Economy: The Struggle for Supremacy in the $21^{\text {st }}$ Century. Cambridge, MA: Cambridge University Press.

Statistisk Arsbok 1982-83. Stockholm: Statistiska Central Byran.

Stockman, David A. 1981. Director, Office of Management and Budget, before the Senate Appropriations Committee, 23 January, 3-4.

Teaster, Joseph B. 2004. Paul Volcker: The Making of a Financial Legend. Hoboken, NJ: John Wiley and Sons.

Time. 1976a. "Sweden: Social Democrats: 44 and out." Time 108 (17): 9.

Time. 1976b. "Personalities: Making It in Sweden." Time 108 (12): 32.

Time. 1980a. "Business: Recession: Long and Deep." Time 115 (24): 48-52.

Time. 1980b. "Nation: Carter's New Economics." Time 116 (10): 34.

Tilly, Charles. 1975. The Formation of Nation States in Western Europe. Princeton, NJ: Princeton University Press.

Wallis, Joe, and Brian Dollery. 1997. "Autonomous Policy Leadership: Steering a Policy Process in the Direction of a Policy Quest." Governance 10 (1): $1-22$.

Wallison, Peter J. 2003. Ronald Reagan: The Power of Conviction and the Success of His Presidency. Boulder, CO: Westview Press.

Walsh, James. I. 2006. "Policy Failure and Policy Change: British Security Policy after the Cold War." Comparative Political Studies 39 (4): 490-518.

Weatherford, M. Stephen, and Lorraine M. McDonnell. 2005. "Ronald Reagan as Legislative Advocate: Passing the Reagan Revolution's Budgets in 1981 and 1982." Congress and the Presidency 32 (1): 1-29.

Whyman, Philip, and Brian. Burkitt. 1993. "The Role of the Swedish Employers in Restructuring Pay Bargaining and the Labour Process." Work, Employment \& Society 7 (4): 603-614.

Weidenbaum, Murray. 2011. The Competition of Ideas: The World of the Washington Think Tanks. New Brunswick, NJ: Transaction Publishers. 